\title{
Designing agromet advisories for selected weather windows under automated weather based advisory system in Tamil Nadu - A case study
}

\author{
T.N. BALASUBRAMANIAN, R. JAGANNATHAN, N.MARAGATHAM, K. SATHYAMOORTHI, \\ R. NAGARAJAN, MALLIGA VANANGAMUDI, N.K. SATHYAMOORTHY, S. POONGUZHALI, \\ P. SAKTHIVEL, S. SATARJI, P. ARUN PRAKASH, P. RAMESH KUMAR, and J. ABDUL HAMEED
}

\author{
Agro Climate Research Centre, Tamil Nadu Agricultural University, Coimbatore - 641003 \\ E-mail: balasubramanian.tnb.tn@gmail.com
}

\begin{abstract}
Research work was undertaken at Agro Climate Research Centre, Tamil Nadu Agricultural University Coimbatore, with the objective of developing agromet advisories for rice crop for 54 independent selected weather windows (SWW) covering eight rice growing seasons/systems of Tamil Nadu. This was done to provide weather-based agromet advisory to the farming community. Weather sensitive rice agromet advisories were developed for its nine stages through group discussions based on rice crop sensitiveness to SWW. The available literature on interaction between rice crop and weather elements at their different threshold levels was also properly considered during this exercise. Proto-type were run for one block of Tamil Nadu and thus problems identified for seeking solutions.
\end{abstract}

Key words: Developing, rice agromet advisories, selected weather window, automated weather advisory, prototype.

Many studies on rice and weather interaction in the past (Oldeman et al., (1986), Venkataraman and Krishnan (1992), Yin et al. (1996), Thakur et al. (2010)) reveals that (i) minimum temperature prevailed during pre-flowering stage of the cool dry season would extend the rice vegetative period, (ii) extremely heavy wet-season rainfall caused crop lodging with flooding, especially during flowering and harvest stages, (iii) high humidity during the wet season and relatively high temperature prevailing during both dry and wet seasons were favoured for heavy infestation of insectpests and diseases, (iv) lower night temperature during postflowering stage had positive correlation with the grain yield and (v) high diurnal differences led to more efficient energy conversion. Thereby suggesting, that the observed weather during crop growing season, would affect rice grain yield both through direct and indirect processes. These impacts or risks could be reduced to a level of minimum, though not fully, with suitable intervention from introduction of weather based agromet advisories, which will guide / help the farmers to take weather based farm decisions / interventions under response farming concept.

Considering this, an attempt was made to develop rice agromet advisories for 54 selected weather windows (SWW) that prevailed in Tamil Nadu covering both spatial and temporal dimensions in the ambit of automated weather based agromet advisory system being operated at ACRC, TNAU, under National Agricultural Development Programme of Government of Tamil Nadu.

\section{MATERIALS AND METHODS}

The development and fine-tuning of agromet advisories for rice crop for 54 selected weather windows (SWW) based on six days weather forecast was undertaken at ACRC of Tamil Nadu Agricultural University, Coimbatore between 2013 and 2014. Alreadyidentified 54 SWW, covering both spatial and temporal dimensions of Tamil Nadu weather (Balasubramanian et al., 2014) were the base for defining the agromet advisories for rice in the present study and selected 18 are given in Table 1. The sequential steps to provide automated weather based rice agromet advisories to farmers through Short Message Service (SMS) to their mobiles are given below:

The already developed and validated $54 \mathrm{SWW}$, which contain ranges of each weather element (means values of six day maximum and minimum temperature; relative humidity and mean wind speed along with six day cumulative rainfall) were uploaded in the database of the server maintained at ACRC.

- The developed agromet advisories for each stage of rice for $54 \mathrm{SWW}$ were also uploaded on the server. To 
Table 1: Selected weather windows (SWW) (absolute range values)

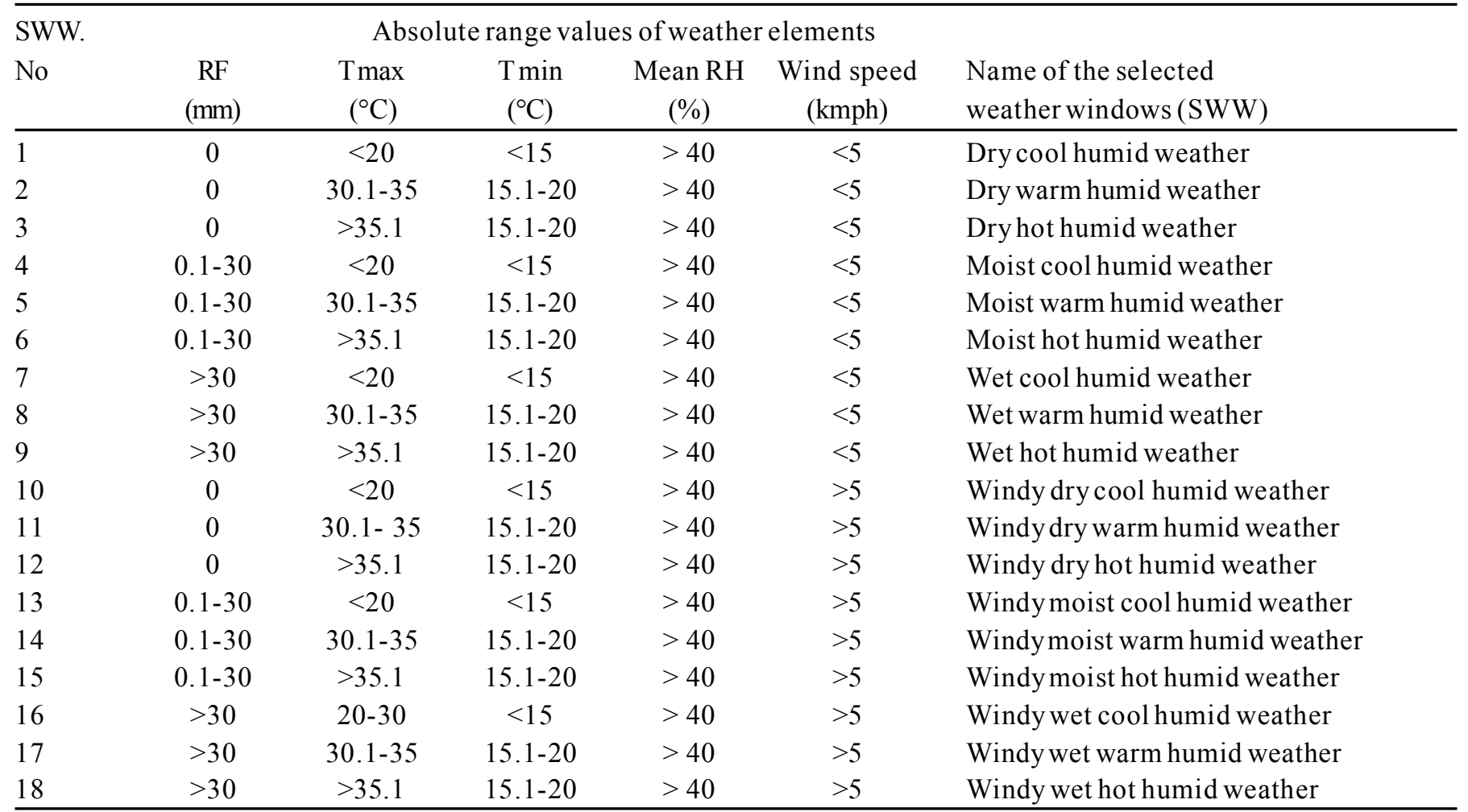

develop appropriate agromet advisories for rice crop for the selected $54 \mathrm{SWW}$, initially four group discussions were organized with subject experts from agronomy, plant pathology, agricultural entomology, crop physiology, agrometeorology, agricultural extension and farmers from rice growing tracts. Thereafter, based on the literature, current available research information and group consensus, the weather based crop agromet advisories were fine tuned for nine crop stages of rice (Table 2). These nine stages of rice crop were chosen after a thorough group discussion with the farmers and extension workers in the State.

- $\quad$ The Automatic Weather Stations (AWS) installed in each block ( 385 blocks) were directly uplinked with the server maintained at ACRC, TNAU to have daily weather profile of the concerned block parameters including maximum and minimum temperature, relative humidity, wind speed and rainfall.

- Using the regional climate model (Weather Research Forecast), weather forecast were developed with lead-time of six days by utilizing Global Forecasting System outputs of National Centre for Environment Prediction, USA and the AWS observed weather over past six days.

- $\quad$ The information on observed weather over past six days and the forecast developed for the next six days, will then get automatically compressed to mean values for maximum and minimum temperature, relative humidity, wind speed and cumulative six days rainfall to arrive a SWW in respect of forecasted and observed weather.

- Based on the information on growth stage of the rice as fed by the extension officials via World Wide Web to the ACRC server on every Monday at block level, the relevant agromet advisory for rice to the SWW as above will be picked up by the programme automatically and get communicated to the farmers as SMS to their mobile phones. For this purpose 100 mobile numbers of farmers from each block were included in the database of the server. These agromet advisory were thus sent on every Monday with lead time of six days (from Tuesday to Sunday) to guide / help farmers to take weather based farm decisions.

\section{RESULTS AND DISCUSSION}

The agromet advisories(for 18 only as an example) on rice developed for $54 \mathrm{SWW}$ for nine growth stages are given in Table 2 (a-e). In response to each SWW the relevant agromet advisory was prepared taking into account expected grain loss with the SWW and percentage of risk reduction with the application of agromet advisory. The agromet advisory included forecast for daily means of maximum and minimum temperature, relative humidity, wind speed and cumulative rainfall. 
Table 2 : Agromet advisories of rice for 18 selected weather windows ( $\mathrm{SWW}$ ) of Tamil Nadu (a) for cropstages $\mathrm{R}_{1}, \mathrm{R}_{2}$ and $\mathrm{R}_{3}$

\begin{tabular}{|c|c|c|c|}
\hline Crop Stages & $\begin{array}{l}\text { Past observed } 6 \text { days } \\
\text { weather data }\end{array}$ & $\begin{array}{l}\text { Weather forecast for } 6 \\
\text { days }\end{array}$ & Agromet advisory \\
\hline \multirow[t]{3}{*}{$\begin{array}{l}\mathrm{R} 1 \text { : Nursery } \\
\text { Preparation }\end{array}$} & $\begin{array}{l}\text { Rainfall from } 0.1 \\
\text { to }>30 \mathrm{~mm} \text { and other } \\
\text { weather elements not } \\
\text { considered (SWW: } 4,5,6 \text {, } \\
13,14 \text { and } 15)\end{array}$ & - & $\begin{array}{l}\text { AA 1. Rainfall received in past six days may be } \\
\text { used to puddle the soil for nursery bed } \\
\text { preparation to save irrigation water } \\
\text { and achieve higher rainfall use efficiency }\end{array}$ \\
\hline & - & $\begin{array}{l}\text { Rainfall from } 0.1 \text { to } \\
>30 \mathrm{~mm} \text { and other } \\
\text { weather elements not } \\
\text { considered } \\
\text { (SWW: } 4,5,6,13,14 \\
\text { and } 15)\end{array}$ & $\begin{array}{l}\text { AA 1.The anticipated rainfall may be used for } \\
\text { preparing rice nursery } \\
\text { AA 2. For the sown rice nursery, anticipating } \\
\text { rainfall, impound water over the seeds sown in the } \\
\text { nursery during evening and drain it by next day } \\
\text { morning so as to prevent somersaulting of sown } \\
\text { seeds with rainfall against poor germination }\end{array}$ \\
\hline & $\begin{array}{l}\text { Rainfall from } 0.1 \text { to } \\
30 \mathrm{~mm} \text { and other } \\
\text { weather elements not } \\
\text { considered } \\
\text { (SWW: } 4,5,6,13,14 \\
\text { and } 15 \text { ) }\end{array}$ & $\begin{array}{l}\text { Rainfall from } 0.1 \text { to } \\
>30 \mathrm{~mm} \text { and other } \\
\text { weather elements not } \\
\text { considered } \\
\text { (SWW: } 4,5,6,13,14 \\
\text { and } 15)\end{array}$ & $\begin{array}{l}\text { AA 1. Continuous rainfall situation may affect } \\
\text { nursery preparation and hence impound the } \\
\text { rainwater in the field where ever possible. } \\
\text { AA 2. For the sown rice nursery, anticipating } \\
\text { rainfall, impound water over the seeds sown in the } \\
\text { nursery during evening and drain it by next day } \\
\text { morning so as to prevent somersaulting of sown } \\
\text { seeds against poor germination }\end{array}$ \\
\hline $\begin{array}{l}\text { R2: Two leaf } \\
\text { stage } \\
\text { seedlings }\end{array}$ & $\begin{array}{l}\text { Rainfall }>30 \mathrm{~mm} \text { and } \\
\text { other weather elements } \\
\text { not considered } \\
\text { (SWW: } 7,8,9,16,17 \\
\text { and } 18 \text { ) }\end{array}$ & $\begin{array}{l}\text { Rainfall }>30 \mathrm{~mm} \text { and } \\
\text { other weather elements } \\
\text { not considered } \\
(\mathrm{SWW}: 7,8,9,16,17 \\
\text { and } 18) \text { ) }\end{array}$ & $\begin{array}{l}\text { Considering the receipt of heavy rainfall and also } \\
\text { with anticipating heavy rainfall, provide drainage } \\
\text { to rice nursery against rotting of seedlings with } \\
\text { water stagnation. Close all water entry points in } \\
\text { the field against flooding. }\end{array}$ \\
\hline \multirow[t]{2}{*}{$\begin{array}{l}\text { R3: Three to } \\
\text { four leaf stage } \\
\text { seedlings }\end{array}$} & $\begin{array}{l}\text { Maximum temperature } \\
>35.1^{\circ} \mathrm{C} \text { with } \mathrm{RH}>40 \% \\
\text { and other weather } \\
\text { elements not } \\
\text { considered } \\
\text { (SWW: } 3,12 \text { and } 18 \text { ) }\end{array}$ & $\begin{array}{l}\text { Maximum temperature } \\
>35.1^{\circ} \mathrm{C} \text { with } \mathrm{RH}> \\
40 \% \text { and other } \\
\text { weather elements not } \\
\text { considered(SWW: } 3,12 \\
\text { and } 18)\end{array}$ & $\begin{array}{l}\text { The prevailing and anticipated weather with high } \\
\text { temperature and high relative humidity may result } \\
\text { in thrips and jassid attack in young rice seedlings. } \\
\text { Monitor the pest population and adopt plant } \\
\text { protection measures in consultation with } \\
\text { extension specialist. }\end{array}$ \\
\hline & $\begin{array}{l}\text { Minimum temperature } \\
<15^{\circ} \mathrm{C} \text { with } \mathrm{RH}>40 \% \\
\text { and other weather } \\
\text { elements not considered } \\
(\mathrm{SWW}: 1,4,7,10 \text {, } \\
13 \text { and } 16)\end{array}$ & $\begin{array}{l}\text { Minimum temperature } \\
<15^{\circ} \mathrm{C} \text { with } \mathrm{RH}>40 \% \\
\text { and other weather } \\
\text { elements not } \\
\text { considered } \\
\text { (SWW: } 1,4,7,10,13 \\
\text { and } 16)\end{array}$ & $\begin{array}{l}\text { The prevailing and anticipated weather with low } \\
\text { temperature and high relative humidity may affect } \\
\text { rice seedlings with fungal diseases. Monitor the } \\
\text { disease intensity and take plant protection in } \\
\text { consultation with Agricultural Specialist. }\end{array}$ \\
\hline
\end{tabular}

The ACRC, TNAU has developed a proto-type software to disseminate agromet advisory through SMS to the farmers of a block. Trial runs of software were made to identify the problems before its finalization for all 385 blocks. Ex-ante analysis through partial budgeting was done for three selected agromet advisories from Table 2 (a,b $\&$ c) to examine the benefits likely to be accrued with the adoption of agromet advisories for SWW.

\section{Agromet advisory during nursery establishment (R1)}

The stage of the rice crop is one day nursery sown 
Table 2(b): Agromet advisories for Crop stages $\mathrm{R}_{4}$ and $\mathrm{R}_{5}$

\begin{tabular}{|c|c|c|c|}
\hline Crop Stages & $\begin{array}{l}\text { Past observed } 6 \text { days } \\
\text { weather data }\end{array}$ & $\begin{array}{l}\text { Weather forecast for } 6 \\
\text { days }\end{array}$ & Agromet advisory \\
\hline \multirow[t]{2}{*}{$\begin{array}{l}\text { R4: Preparation } \\
\text { of the main field } \\
\text { and } \\
\text { transplanting }\end{array}$} & $\begin{array}{l}\text { Rainfall from } 0.1 \text { to }>30 \\
\text { mm and other weather } \\
\text { elements Not considered } \\
(\mathrm{SWW}: 4,5,6,13,14 \text { and } 1\end{array}$ & 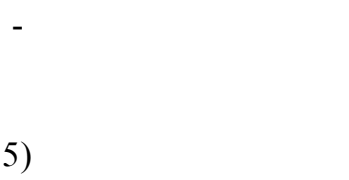 & $\begin{array}{l}\text { Prepare the main field for transplanting rice with } \\
\text { the amount of rainfall received so as to save both } \\
\text { ground and surface water sources. }\end{array}$ \\
\hline & & & $\begin{array}{l}\text { AA3 In case of prediction of likely wet spell, stop } \\
\text { transplanting and also don't apply basal } \\
\text { application of NPK fertilizer. }\end{array}$ \\
\hline $\begin{array}{l}\text { R5: Established } \\
\text { seedlings and } \\
\text { tillering stages }\end{array}$ & $\begin{array}{l}\text { Maximum temperature } \\
>35.1^{\circ} \mathrm{C} \text { with } \mathrm{RH}>40 \% \\
\text { and other weather } \\
\text { elements not considered } \\
(\mathrm{SWW}: 3,12 \text { and } 18)\end{array}$ & $\begin{array}{l}\text { Maximum temperature } \\
>35.1^{\circ} \mathrm{C} \text { with } \mathrm{RH} \\
>40 \% \text { and other } \\
\text { weather elements } \\
\text { not considered } \\
(\mathrm{SWW}: 3,12 \text { and } 18)\end{array}$ & $\begin{array}{l}\text { The prevailing and anticipated weather with high } \\
\text { temperature and high relative humidity may result } \\
\text { in thrip and jassid attack on rice seedlings. } \\
\text { Monitor the pest population and take plant } \\
\text { protection in consultation with extension } \\
\text { specialist. }\end{array}$ \\
\hline
\end{tabular}

with pre-germinated seeds. The sensitiveness of the crop stage to rainy weather is anticipated to be 60 per cent in terms of failure of nursery establishment due to somersaulting of sown seeds under impact of raindrops. The proposed agromet advisory is to irrigate the nursery during evening hours of a day anticipating rainfall and drain it on next day morning and this be continued for two days till the rice plumule comes-up. Farmers do not practice any contingency measure for this type of weather situation since nursery area is too small for them and would not lead to any substantial economical loss. But in reality, this may not be so. Though, this may be small at individual farm level, but when considered over blocks in the State, the area would be quite significant.

\section{Agromet advisory during peak vegetative growth (R5)}

The sensitiveness of the crop stage to rainy weather is that the number of tiller production would be less by 15 per cent with additional rainwater stagnation in case proper drainage is not provided. The proposed agromet advisory is to provide drainage to drain excess rainwater so as to create water free environment for proper tiller development. Farmers generally do not adopt any management practice for this 
Table 2(C): Agromet advisories for Crop stages $\mathrm{R}_{6}$

\begin{tabular}{|c|c|c|c|}
\hline Crop Stages & $\begin{array}{l}\text { Past observed } 6 \text { days } \\
\text { weather data }\end{array}$ & $\begin{array}{l}\text { Weather forecast for } 6 \\
\text { days }\end{array}$ & Agromet advisory \\
\hline \multirow[t]{7}{*}{$\begin{array}{l}\text { R6: Maximum } \\
\text { tillering and } \\
\text { panicle } \\
\text { initiation stage }\end{array}$} & $\begin{array}{l}\text { Wind speed }>5 \mathrm{kmph} \\
\text { and other weather } \\
\text { parameters not } \\
\text { Considered } \\
\text { (SWW: } 10 \text { to } 18 \text { ) }\end{array}$ & $\begin{array}{l}\text { Wind speed }>5 \mathrm{kmph} \\
\text { and other weather } \\
\text { parameters not } \\
\text { considered } \\
\text { (SWW: } 10 \text { to } 18 \text { ) }\end{array}$ & $\begin{array}{l}\text { Since the wind speed is more than } 5 \mathrm{kmph} \text { do not } \\
\text { top dress the crop with nutrients through } \\
\text { broadcasting. May go for foliar application of } \\
\text { Nitrogen and Potash if need arises. }\end{array}$ \\
\hline & $\begin{array}{l}\text { Wind speed } \\
<5 \mathrm{kmph} \text { and } \mathrm{RH} \\
>40 \%+\text { no rain }+ \\
\text { maximum temperature } \\
>20{ }^{\circ} \mathrm{C}(\mathrm{SWW}: 2 \text { and } 3)\end{array}$ & $\begin{array}{l}\text { Wind speed } \\
<5 \mathrm{kmph} \text { and } \mathrm{RH} \\
>40 \%+\text { no rain }+ \\
\text { maximum temperature } \\
>20^{\circ} \mathrm{C}(\mathrm{SWW}: 2 \text { and } 3)\end{array}$ & $\begin{array}{l}\text { Since the weather is calm and dry, may top dress } \\
\text { the Nitrogen and Potassium fertilizers }\end{array}$ \\
\hline & - & $\begin{array}{l}\text { Rainfall }>30 \mathrm{~mm} \text { and } \\
\text { other weather elements } \\
\text { not considered } \\
\text { (SWW: } 7,8,9,16,17 \\
\text { and } 18 \text { ) }\end{array}$ & $\begin{array}{l}\text { AA1In view of anticipating heavy rainfall provide } \\
\text { drainage as the rice is in maximum tillering stage } \\
\text { and flooding may result in poor tillering. } \\
\text { AA2May postpone top dressing of } \mathrm{N} \text { and } \mathrm{K} \\
\text { fertilizers in view of the anticipating heavyrainfall. }\end{array}$ \\
\hline & $\begin{array}{l}\text { Maximum temperature } \\
>35.1^{\circ} \mathrm{C} \text { with } \mathrm{RH} \\
>40 \% \text { and other } \\
\text { weather elements } \\
\text { not considered } \\
(\mathrm{SWW}: 3,12 \text { and } 18)\end{array}$ & $\begin{array}{l}\text { Maximum temperature } \\
>35.1^{\circ} \mathrm{C} \text { with } \mathrm{RH} \\
>40 \% \text { and other } \\
\text { weather elements } \\
\text { not considered } \\
(\mathrm{SWW}: 3,12 \text { and } 18)\end{array}$ & $\begin{array}{l}\text { The prevailing and anticipated weather with high } \\
\text { temperature and high relative humidity may favour } \\
\text { attack of worms in rice. Monitor the pest } \\
\text { population and take plant protection in } \\
\text { consultation with extension specialist. }\end{array}$ \\
\hline & $\begin{array}{l}\text { Rainfall from } 0.1 \text { to } \\
30 \mathrm{~mm} \text { with } \mathrm{RH}>40 \% \\
\text { and other weather } \\
\text { elements not } \\
\text { considered } \\
\text { (SWW:4,5,6,13,14 } \\
\text { and } 15 \text { ) }\end{array}$ & $\begin{array}{l}\text { Rainfall from } 0.1 \text { to } \\
30 \mathrm{~mm} \text { with } \mathrm{RH}>40 \% \\
\text { and other weather } \\
\text { elements not } \\
\text { considered } \\
\text { (SWW:4,5,6,13,14 } \\
\text { and } 15 \text { ) }\end{array}$ & $\begin{array}{l}\text { The cloudy weather with rainfall may favour } \\
\text { infestation by leaf folder and brown plant hopper } \\
\text { in rice. Take plant protection measures under } \\
\text { expert advice. }\end{array}$ \\
\hline & $\begin{array}{l}\text { Temperature }<15^{\circ} \mathrm{C} \\
+ \text { Rainfall }>30 \mathrm{~mm}+ \\
\mathrm{RH}>40 \%(\mathrm{SWW:} 7 \\
\text { and } 16)\end{array}$ & $\begin{array}{l}\text { Temperature }<15^{\circ} \mathrm{C}+ \\
\text { Rainfall }>30 \mathrm{~mm}+ \\
\text { RH }>40 \% \\
\text { (SWW: } 7 \text { and } 16 \text { ) }\end{array}$ & $\begin{array}{l}\text { The weather with rainfall, high relative humidity } \\
\text { and low minimum temperature may cause blast and } \\
\text { Helminthosporium leaf diseases in rice. Consult } \\
\text { extension specialist for undertaking the plant } \\
\text { protection measures. }\end{array}$ \\
\hline & $\begin{array}{l}\text { Rainfall }>30 \mathrm{~mm} \text { and } \\
\text { other weather elements } \\
\text { not considered } \\
\text { (SWW: } 7,8,9,16,17 \\
\text { and } 18 \text { ) }\end{array}$ & $\begin{array}{l}\text { Rainfall }>30 \mathrm{~mm} \text { and } \\
\text { other weather elements } \\
\text { not considered } \\
\text { (SWW: } 7,8,9,16,17 \\
\text { and } 18 \text { ) }\end{array}$ & $\begin{array}{l}\text { The prevailing weather situation may result in } \\
\text { flooding under low land. Consult extension } \\
\text { specialist for expert advice for expert advice on } \\
\text { management strategies for such situations. }\end{array}$ \\
\hline
\end{tabular}

weather situation.

\section{Agromet advisory for blast and Helminthosporium leaf disease management (R6)}

The sensitiveness of these crop stages to the weather situation mentioned above are a yield loss of up to 30 per cent as a result disease infestation if it is not controlled by taking appropriate plant protection measures in consultation with plant pathologist when the disease load crossed threshold level. The proposed agromet advisory is to adopt timely plant protection measures. The present practice generally prevalent with farmers is to go for plant protection measures as per advice of agricultural input dealer rather 
Table 2(d): Agromet advisories for Crop stages $\mathrm{R}_{7}$ and $\mathrm{R}_{8}$

\begin{tabular}{|c|c|c|c|}
\hline Crop Stages & $\begin{array}{l}\text { Past observed } 6 \text { days } \\
\text { weather data }\end{array}$ & $\begin{array}{l}\text { Weather forecast for } 6 \\
\text { days }\end{array}$ & Agromet advisory \\
\hline \multirow[t]{2}{*}{$\begin{array}{l}\text { R7: Flowering } \\
\text { stage }\end{array}$} & $\begin{array}{l}\text { Minimum temperature } \\
<15^{\circ} \mathrm{C} \text { and other } \\
\text { weather elements } \\
\text { not considered } \\
(\mathrm{SWW}: 1,4,7,10,13 \\
\text { and } 16)\end{array}$ & $\begin{array}{l}\text { Minimum temperature } \\
<15^{\circ} \mathrm{C} \text { and other } \\
\text { weather elements } \\
\text { not considered } \\
(\mathrm{SWW}: 1,4,7,10,13 \\
\text { and } 16)\end{array}$ & $\begin{array}{l}\text { AA1 As the prevailing night temperature are low, } \\
\text { to enhance the growth of rice spray } 120 \mathrm{ppm} \\
\text { Salicylic acid ( } 120 \mathrm{mg} \text { in } 1 \text { litre of water) } \\
\text { AA2The prevailing low night temperature is likely } \\
\text { to favour blast disease and sheath rot disease of } \\
\text { rice. Take expert advice from extension specialist } \\
\text { for plant protection measures to be adopted. }\end{array}$ \\
\hline & $\begin{array}{l}\text { Maximum temperature } \\
>35.1{ }^{\circ} \mathrm{C} \text { with } \mathrm{RH} \\
>40 \% \text { and other } \\
\text { weather elements not }\end{array}$ & $\begin{array}{l}\text { Maximum temperature } \\
>35.1^{\circ} \mathrm{C} \text { with } \mathrm{RH} \\
>40 \% \text { and other } \\
\text { weather elements not }\end{array}$ & $\begin{array}{l}\text { The weather with high temperature and high } \\
\text { relative humidity may favour stem borer and } \\
\text { brown plant hopper attack. Consult Extension } \\
\text { specialist for appropriate control measures. }\end{array}$ \\
\hline
\end{tabular}

and 18) (SWW: 3,12 and 18)

Rainfall $>30 \mathrm{~mm}$ and other weather elements not considered (SWW: 7,8, 9,16,17 and 18)

\begin{tabular}{|c|c|c|}
\hline \multirow[t]{2}{*}{$\begin{array}{l}\text { R8: Milking } \\
\text { and grain } \\
\text { development } \\
\text { stage }\end{array}$} & $\begin{array}{l}\text { Maximum temperature } \\
>35.1^{\circ} \mathrm{C} \text { with } \mathrm{RH} \\
>40 \% \text { and other } \\
\text { weather elements not } \\
\text { considered(SWW: } 3,12 \\
\text { and } 18 \text { ) }\end{array}$ & $\begin{array}{l}\text { Maximum temperature } \\
>35.1^{\circ} \mathrm{C} \text { with } \mathrm{RH} \\
>40 \% \text { and other } \\
\text { weather elements not } \\
\text { considered } \\
\text { (SWW: } 3,12 \text { and } 18 \text { ) }\end{array}$ \\
\hline & $\begin{array}{l}\text { Minimum temperature } \\
<15^{\circ} \mathrm{C}+\mathrm{RH}>40 \% \text { and } \\
\text { weather elements are } \\
\text { not considered } \\
\text { (SWW:1,4,7,10,13 } \\
\text { and } 16 \text { ) }\end{array}$ & $\begin{array}{l}\text { Minimum temperature } \\
<15^{\circ} \mathrm{C}+\mathrm{RH}>40 \% \\
\text { and other weather } \\
\text { elements are not } \\
\text { considered } \\
\text { (SWW:1,4,7,10,13 } \\
\text { and 16) }\end{array}$ \\
\hline
\end{tabular}

than to contact extension specialist for proper advice on choice of chemical, its dose and dilution.

The study hypothesis envisaged that whenever weather based agromet advisory is adopted by the farmers, there would be profound reduction in rice crop production risks. The examination of the results of proto-type testing for single block revealed positive signal. However, the benefits of these agromet advisories have to be monitored closely over seasons with the farmers and accordingly they have to be redefined in terms of technical feasibility and sociocultural acceptability for better mass adoption among stakeholders.

Venkataraman and Krishnan (1992), have reported that many crops are highly sensitive to weather elements throughout their growth, while many others were sensitive to weather elements during certain stages only. Considering the philosophy and science, nine stages have been considered for providing agromet advisories to rice crop.

Parvinder Maini and Rathore (2011) from their study made in India reported that farmers who adopted medium range weather based agromet advisories did accrue a net physical benefit of 10 to 15 per cent higher yield for the agricultural crops tested and also there was reduction in the cost of cultivation by 2 to 5 per cent as compared to the nonadoption. Based on the experiences gained from these results greater scope exists across globe to use this research strategy to reduce the weather related rice crop production risks. Further plans have to be done to develop self-learning 
Table 2(e): Agromet advisories for Crop stages $\mathrm{R}_{9}$

\begin{tabular}{|c|c|c|c|}
\hline Crop Stages & $\begin{array}{l}\text { Past observed } 6 \text { days } \\
\text { weather data }\end{array}$ & $\begin{array}{l}\text { Weather forecast for } 6 \\
\text { days }\end{array}$ & Agromet advisory \\
\hline \multirow[t]{4}{*}{$\begin{array}{l}\text { R9: Maturity } \\
\text { and harvesting } \\
\text { stage }\end{array}$} & - & $\begin{array}{l}\text { Rainfall }>30 \mathrm{~mm} \text { and } \\
\text { other weather elements } \\
\text { not considered } \\
\text { (SWW: } 7,8,9,16,17 \\
\text { and } 18 \text { ) }\end{array}$ & $\begin{array}{l}\text { AA1In view of anticipated heavy rainfall, may } \\
\text { postpone the harvest and provide drainage. }\end{array}$ \\
\hline & - & $\begin{array}{l}\text { Rainfall }>30 \mathrm{~mm}+ \\
\text { wind speed }>5 \mathrm{kmph} \\
(\mathrm{SWW}: 16,17 \text { and } 18)\end{array}$ & $\begin{array}{l}\text { Anticipating heavy rainfall with heavy wind, press } \\
\text { the matured plants inward to centre of the field } \\
\text { along the border to avoid lodging and also } \\
\text { provide field drainage. }\end{array}$ \\
\hline & $\begin{array}{l}\text { Minimum temperature } \\
<15^{\circ} \mathrm{C}+\mathrm{RH}>40 \% \\
\text { and other weather } \\
\text { elements are not } \\
\text { considered } \\
\text { (SWW: } 1,4,7,10,13 \\
\text { and } 16 \text { ) }\end{array}$ & $\begin{array}{l}\text { Minimum temperature } \\
<15^{\circ} \mathrm{C}+\mathrm{RH}>40 \% \\
\text { and other weather } \\
\text { elements are not } \\
\text { considered } \\
\text { (SWW:1,4,7,10,13 } \\
\text { and } 16 \text { ) }\end{array}$ & $\begin{array}{l}\text { The prevailing low temperature with high relative } \\
\text { humidity may lead to discoloration of the matured } \\
\text { rice grains. Monitor the grain colour and if } \\
\text { required adopt plant protection measures in } \\
\text { consultation with extension specialist. }\end{array}$ \\
\hline & $\begin{array}{l}\text { No rainfall }+ \text { Maximum } \\
\text { temperature }>20^{\circ} \mathrm{C} \\
\text { (SWW:1,4,7,10,13 } \\
\text { and } 16)\end{array}$ & $\begin{array}{l}\text { No rainfall }+ \text { Maximum } \\
\text { temperature }>20^{\circ} \mathrm{C} \\
(\mathrm{SWW}: 1,4,7,10,13 \\
\text { and } 16)\end{array}$ & $\begin{array}{l}\text { The prevailing weather is conducive for rice } \\
\text { harvesting and hence may undertake harvesting, } \\
\text { winnowing and drying operations as the case may } \\
\text { be. }\end{array}$ \\
\hline
\end{tabular}

(AA-Agromet Advisory)

heuristic models and simulate the required results for finetuning of the developed agromet advisories.

\section{REFERENCES}

Balasubramanian, T.N., R. Jagannathan, N. Maragatham, K. Sathyamoorthiand R. Nagarajan.(2014). Generation of weather windows to develop agro advisories for Tamil Nadu under automated weather forecast system J. Agrometeorol., 16 (1). 60-68.

Gonzales, C.M and Van Der Veen, M.G. (1986). Designing technically feasible and economically viable cropping patterns: Ex-ante; In Training materials of Farming systems socioeconomic research training course, volume 2. Agricultural Economics Department, International Rice Research Institute, Los Banos' Laguna, Philippines. 505-525.

Oldeman, L.R., D.V. Seshu, F.B. Cady. (1986). Response of rice to weather variables. In: Weather and rice, Proceedings of the international workshop on The Impact of Weather
Parameters on Growth and Yield of Rice, Organized by the International Rice Research Institute, Los Baños, Philippines. 7-10 Apr 1986 (http://books.irri.org/ 9711041782 _content.pdf)

ParvinderMaini and L.S. Rathore. (2011). Economic impact assessment of the Agrometeorological Advisory Service of India.Current Sci., 101 (10): 1296 - 1310.

Thakur, P., S. Kumar, J.A. Malik, J.D. Berger, H. Nayyar. (2010). Cold stress effects on reproductive development in grain crops: An overview. Environ. Exper. Botany., 67: 429-443.

Venkataraman, S. (1992). Weather relations of crops. (In: Crops and weather; Eds: Venkataraman, S. and A. Krishnan) pp302-457. Indian Council of Agricultural Research, New Delhi.

Yin, X., M.J. Kropff and J. Goudriaan. (1996). Differential Effects of Day and Night Temperature on Development to Flowering in Rice. Annals Botany, 77: 203-213. 